
РАДУ У ОБЛАСТИ ВОЈНЕ ПСИХОЛОГИЈЕ ПУКОВНИКА И ПРОФ. ДР ПЕТРА КОСТИЋА

\begin{abstract}
САЖЕТАК. У раду је приказан научноистраживачки рад у области војне психологије пуковника и професора Петра Костића. Анализа радова и кључних дела за формирање и развој војне психологије на овим просторима, каријерни развој, као и официрски карактер описан је указивањем на аутобиографске чињенице, цитирањем професорових дела која на најбољи начин осликавају поглед на свет, људе и војничку професију и улогу војног психолога у јединици и улогу официрског кадра у формирању кохезивне јединице спремне за реализацију најтежих војничких задатака. Научноистраживачки радови приказани су у складу са временом настанка у интервалима од 1974. до 1980. године, од 1981. до 1990. године, од 1991. до 2004. године, и период након престанка професионалне војне службе. Приказ радова прати, поред временског одређења настанка дела, и место рада и официрски чин, чиме се указује на неопходност поступности у професионалном развоју официра и психолога, која доводи до зрелости у истраживачком раду, тумачењу емпиријских података и разумевању војног окружења. У чланку су поред научноистраживачких радова, приказани и људи са којима је радио и истраживао професор Костић. Приказом истраживачких тимова, може се увидети да је током своје професорске и истраживачке каријере професор Костић сарађивао са људима који су оставили неизбрисив траг у психоло-
\end{abstract}

anita.djordjevic@mod.gov.rs

Радје примљен 13. фебруара, а прихваћен за објављивање на састанку Редакције 3борника одржаном 30. марта 2020. 
гији генерално, али и у војној психологији, психијатрији, андрагогији и социологији. Из анализе радова може се закључити да је за стварање и развој неке наставне и научне области потребно пуно систематског рада и личног одрицања, широког општег образовања, ведрог и радозналог духа, као и најважнији фактор - људи, односно сарадници са којима се јасно препознаје циљ који се жели постићи.

КљУЧНЕ РЕЧИ: човек у одбрани; официр; научноистраживачки рад; војна психологија.

Петар Костић, пуковник и професор, доктор психолошких наука свој животни и професионални пут везао је за војну професију и вољену домовину.

Сматра се једним од оснивача војне психологије на просторима СФРЈ и потоњих држава закључно са Републиком Србијом. Својим радом стварао је академску и струковну војну психологиjу, на почетку рада менторским вођењем зачетника војне психологије на овом простору, проф. др Десимира Пајевића и проф. др Љубомира Касагића, а касније и самосталним и тимским научноистраживачким радом. И након формалног завршетка војничке каријере, професор Костић је наставио са истраживањима психолошких проблема човека у одбрани и војсци, сарађујући са војним психолозима који су неретко били и његови студенти, што са Војне академије или Филозофског факултета у Нишу.

Историја развоја војне психологије у Србији је богата и садржајна. Можемо се похвалити да су у војсци радили и раде људи који су у српском друштву и психологији као науци оставили лични печат. Пуковник и професор Петар Костић са већином наведених психолога је у исто време радио у војсци, а са добрим делом психолога је радио на стварању војне психологије и школовању будућих војних психолога и официра. Војна психологија темељи се на њиховим идејама и научним радовима, а то су: Живорад-Жижа Васић, генерал-потпуковник Кроња Томислав, пуковник Вукомановић Софија, пуковник Капор Гојко, пуковник Јовићевић Миланко, Стрмотић Емилија, пуковник Главач Томо, капетан бојног брода проф. др Арнаутовић Драгољуб, Добривојевић Илија, проф. др Цмелић Стојан, проф. др Шуковић Филип, проф. др Јосип Бергер, проф. др Константин Момировић, пуковник проф. др Џамоња Звонимир, Мара Ђакић, потпуковник проф. др Ранко Поповић, Бенић Недељко, проф. др Александар Буквић, проф. др Предраг Огњеновић, Душан Илић, љубомир-љуба Сто- 
јић, пуковник Јанша Милојка, пуковник проф. др Братислав Петровић, потпуковник Видаковић Лазар, пуковник мр Берић Марица, др Мићовић Милорад, проф. др Десимир Пајевић, пуковник Миловановић Радојко, проф. др Љубомир Касагић, проф. др Сулејман Хрњица, проф. др Перо Шипка, Мајерле Мирко, Поповић Вера, пуковник Милојевић Велибор, Антић Владимир, др Петровић Стеван - Вања, Покрајац Бранко, Филиповић Велимир, Валерије-Вања Љубичић, потпуковник Милковски Миле, спец. Трлаја Љиљана, проф. др Чабаркапа Миланко, Данић Нада, проф. др Чолаковић Радомир, мр Селимбеговић Ирена, обрадовић Борко, мр спец. Милавић-Вујковић Мерица, проф. др Миодраг Миленовић, Мратинковић Марта (дев. Ловре), спец. Рођенков-Милинковић Сања, потпуковник Јоцић Радослав, др Аларгић Драгана, мр Дражић Радојка, Драгићевић В. Даниела, проф. др Стефановић-Станојевић Татјана, Ћелап Ана, мр Верица Димитријевић, спец. Божиновић Вера, спец. Стојановић Татјана (дев. Алачов), спец. Вучековић Наташа, МА и спец. Јовановић Сузана, научни сарадник и доцент Анита Пешић (дев. Ђорђевић), мајор Петровић Мирослав, којима смо захвални на интелектуалној заоставштини. Сарадници у раду са професором Костићем су и андрагози Института ратне вештине/Института за стратегијска истраживања, пуковници: проф. др Марчек Јан, проф. др Килибарда 3оран, проф. др Суша Будислав. Сарадници у раду војнопсихолошке службе су психолози који су формално управљали развојем војне психологије начелници војнопсихолошке служठе који су истовремено ठили и први сарадници пуковника Петра Костића: генерал-мајор проф. др Милорад Ђорђевић, од кога пуковник Костић преузима дужност и психолог др Драгана Аларгић којој предаје дужност.

Пуковник и професор Петар Костић запамћен је од својих студената (питомаца и кадета) из Војне академије као строг и захтеван селекциони психолог, доследан у поштовању и примени психолошких критеријума за пријем кандидата за школовање на Војној академији, потом професор, старешина и психолог који поштује војничко васпитање и даје лични пример млађима - кадетима и старешинама. Његови студенти, које је неретко звао борцима, а који су стицајем политичких и војничких околности и реално постали борци, памте га као професора и старешину, лојалног домовини, војсци и својим саборцима. Своје „борце“пуковник и професор није заборавио ни у најтежим војничким тренуцима, добровољним учешћем у грађанском рату, обилазио је 
своје студенте-борце на ратиштима Славоније, Далмације и Лике. Психолошки је важно и интересантно да је своје студенте-борце обилазио када су били на почетним старешинским дужностима, кад им је сусрет са грађанским ратом, разорним дејством оружја и људским страдањима било тешко животно искуство, али и касније, кад су исти постали старешине које су поседовале животно и професионално искуство током НАТО агресије на Савезну Републику Југославију 1999. године.

Специфичним војничким и стваралачким духом својим борцима уливао је снагу и подсећао их да је страх у рату нормална биолошка појава и да их тај страх чува од несмотрених и „лудих“ акција и реакција, да ће се страх смањити пролажењем кроз реална борбена дешавања, да им најпречи буде морални страх - да не оставе и не издају свог војника ни саборца, јер ће им тај страх трајати дуже од ратног. Саветовао их је да ће их у рату најбоље чувати њихова присебност, знања и вештине из војничке обуке, њихова физичка и здравствена спремност, орни дух али и добра кохезија војне јединице и веза са њиховим саборцима. Тим приликама, професорски смирено и војнички дисциплиновано указивао им је на знања из војне психологије о понашању човека у рату, чији значај нису могли у потпуности да разумеју у мирнодопском времену. Касније је, своја војничка, ратна и мирнодопска сазнања и емоционалне доживљаје и осећаје, теоријски и емпиријски истраживао и уградио у наставне теме програма Војне психологије у Војној академији, као и у публикацију Психолоїија борбене јеguнице (Костић, 2000) коју је неретко поклањао својим мирнодопским студентима који су током професионалне каријере постали искусни борци.

Поред редовних наставних тема предмета војне психологије, од непроцењиве су важности наставне теме које најјасније објашњавају и дочаравају емоционални доживљај човека (војника, старешине) током припреме за прву борбу и упућивање на подручје ратних дејстава, у току ратних дејстава, непосредно после прве борбе или ратног дејства, периода после односно повратка ратника на безбедну територију, војну организацију, цивилно друштво и породичну средину.

Ретки су случајеви и у свету да су наставне теме у предмету војне психологије писали професори који имају високе војне школе и највиша академска знања из психологије, а уз све то искуства у војној психолошкој селекцији, војном школовању и оружаној борби - грађанском рату уз и са својим студентима-војни- 
цима-борцима. Ту привилегију има војна психологија која се изучава на Војној академији и која се изучавала за време професора Петра Костића на појединим факултетима. Ако се сматра да је пуковник проф. др Џамоња Звонимир увео војну психологију у наставне програме цивилних факултета првенствено Филозофског факултета, пуковник проф. др Петар Костић је свакако настављач тог посла.

У наставку текста, потрудићу се да што јасније и концизније прикажем научноистраживачки рад у области војне психологије професора Петра Костића у интервалним периодима стварања и институцијама у којима је радио.

РАДОВИ ИЗ ВОЈНЕ ПСИХОЛОГИЈЕ У ПЕРИОДУ ОД 1974. ДО 1980. ГОДИНЕ

По завршетку Војне академије смера пешадије у Сарајеву 1972. године потпоручник Костић почиње војничку каријеру у Смедеревској Паланци као командир војничког вода и чете до 1978. године. Истовремено, ванредно се школовао на Филозофском факултету у Београду на одељењу за психологију, где је и дипломирао.

Капетан Костић 1978. године постаје референт за војни психологију у Наставном одсеку Центра високих војних школа у Београду, а током 1979. референт за војну психологију у Наставно-научном одсеку Војне академије. Исте године, ангажован је на истраживачком задатку „Проблеми формирања и деловања питомачких колектива“ којим је руководио мр Љубомир Касагић. Из тог задатка написана је студија под називом Неки ӣроблеми

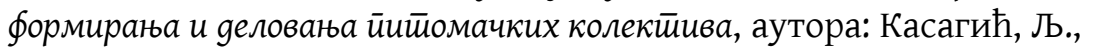
Костић, П., Бауцал, Д. и Зорић, Д. (1979) из Центра високих војних школа, Војне академије родова КоВ и интендантске службе у Београду.

Студија се састоји од пет целина, и то: 1 . Изграђеност питомачких колектива; 2. Чиниоци психолошке зрелости питомачког колектива (групна тензија, афективна атмосфера, групна кохезија и групна експанзија); 3. Чиниоци и неки индикатори ефикасности питомачких колектива; 4. Опажање (перцепција) социјалне прихваћености питомаца у колективу; 5. Чиниоци социјалне прихваћености у питомачким колективима.

Ова истраживачка тема емпиријски је проверавана због изузетне важности функционисања војничког колектива за могућност реализације задатака у војсци и одбрани. Колектив у психо- 
социјалном смислу, према Љ. Касагићу, подразумева неколико ठитних карактеристика: „прихваћени заједнички циљеви, циљеви пожељни за све питомце као појединце и за колектив као целину, колективно прихваћени начини понашања у остваривању постављених циљева, постоје „ми-осећаји“, осећај припадности свом колективу и постоји позитивна и слободна комуникација међу члановима која се заснива на сарадњи, узајамној помоћи, прихватању и поштовању норми понашања (морал колектива). Осим тога, изграђени питомачки колективи имају још и следеће карактеристике: прихватање вође (командира) као „свог“ човека, одсуство самодовољности у остваривању циљева; прихватање специфичних вредности које су обележја професије (војнички став и држање, дисциплина, субординација као друштвени однос итд.) због уверености и колективног мњења у том смислу“ (Касагић и сар., 1979, стр. 26).

У истраживању је коришћена Скала изграђености питомачких колектива. Зависну варијаблу у овом истраживању чинила је изграђеност питомачких колектива, а независне варијабле су чинили: 1) ефикасност колектива; 2) социјална клима и зрелост питомачких колектива; 3) социјално порекло питомаца; 4) врста претходно завршене школе; 5) успех у претходно завршеној школи; 6) успех питомаца у Академији.

Узорак испитаника је чинило 495 питомаца Војне академије, подељен у зависности од завршене средње школе, школског успеха у средњошколском и студентском периоду школовања. Истраживање и потоња студија дала су одговоре на важна питања војног школства и критеријума психолошке селекције будућих студената и ученика.

РАДОВИ ИЗ ВОЈНЕ ПСИХОЛОГИЈЕ У ПЕРИОДУ ОД 1981. ДО 1990. ГОДИНЕ

Капетан прве класе Костић након успешног истраживања питомачких колектива наставља истраживањем особина личности за обављање старешинских дужности, које је публиковано 1984. го-

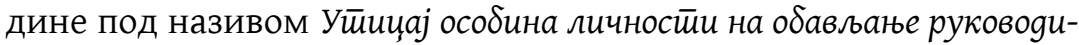
лачких улоїа у војном колекӣиву (Костић, 1984). У блиском временском периоду сарадници кап. 1. класе Костића, аутори и професори Коста Момировић, Звонимир Џамоња, Анкица Хошек,

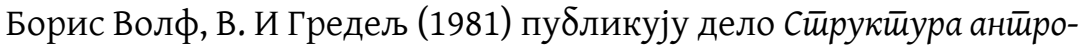
йолошких guмензија војника ЈНА, у издању Војномедицинске академије. 
Мајор Костић наставља истраживачки рад у тиму са сарадницима: вођа тима др Десимир Пајевић, чланови истраживачког тима Марта Ловре, Маравић (1987). Истраживање је имало за циљ сазнавање вредносних оријентација и животних стилова питомаца Војне академије. У овом истраживању аутори су пошли од дефиниције која одређује вредности као „релативном стабилне, опште и хијерархијски организоване карактеристике појединаца и група које су формиране међусобним деловањем историјских, актуелно-социјалних и индивидуалних чинилаца, а које, због тако прописане пожељности, усмеравају понашања својих носилаца ка одређеним циљевима“. Међутим, дотадашња истраживања вредносних оријентација код наше омладине су показала „да су оне код младих доста различите и зависе од школског образовања, социјалног порекла, културног и образовног нивоа средине, при чему друштвене прилике значајно утичу на њихову структуру и стабилност“" (Пајевић и сар., 1987, стр. 41).

Проблем овог истраживања чиниле су вредносне оријентације као „опште и релативно стабилне карактеристике личности које опредељују социјално понашање појединаца у остваривању друштвено позитивних циљева“, као и животне оријентације „преферирани облици понашања кроз које би личност најрадије задовољила своје потребе“ (Пајевић и сар., 1987, стр. 41-42). Испитиване су следеће вредносне оријентације: „материјална; тежња за вођством; индивидуализам-колективизам; друштвено ангажовање; самодетерминација; ауторитарност; оријентација ка променама; доминантност; мотив за постигнућем, имплицитна педагогија“. Преференција животних стилова обухватала је следеће оријентације: „хуманистичку, материјалистичку, алтруистичку, естетску, оријентацију на моћ и углед, сазнајну, ка саамоактуализацији, активистичко-револуционарну“" (Пајевић и сар., 1987, стр. 42). Истраживање је обављено на узорку од 211 питомаца 42. класе Војне академије, а за испитивање је коришћена скала вредности стандардизована у Институту за психологију Филозофског факултета у Београду.

Испитивањем је установљено да је код питомаца „најизраженија вредносна оријентација колективизам, следе толерантност, вођство, оријентација ка променама, имплицитна педагогија, самодетерминација, друштвено ангажовање, доминантност и ауторитарност, на нивоу просека су изражене материјалне оријентације и жеља за постигнућем“ (Пајевић и сар., 1987, стр. 42). 
Добијени резултати истраживања, поред регистровања доминантних вредносних оријентација и животних стилова питомаца ठудућих официра, указали су и на могућност утицаја и промена одређених вредности кроз васпитни рад у војној организацији.

Временски период од 1981. до 1990. године у развоју предмета војне психологије може се окарактерисати периодом интензивног истраживачког и наставног рада и формирања и публиковања уџбеника Војне психологије за студенте-кадете Војне академије. Уџбенике пишу тимови: Пајевић, Д., Касагић, Љ., Шипка, П. (1987): Основи војне ӣсихолоїије, Центар високих војних школа КоВ ЈНА, Војна академија Копнене војске, Београд; Арнаутовић, Д., Касагић, Љ., Пајевић, Д. (1988): Војна йсихолоїuја, Савезни секретаријат за народну одбрану, Генералштаб оружаних снага СФРЈ, IV управа, Београд; Пајевић, Д., Требјешанин, Б. (1988): Основи йси-

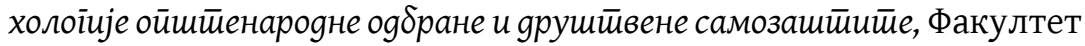
ОНО, Београд; Касагић, Љ., Пајевић, Д., Костић, П., Ловре М. (1990):

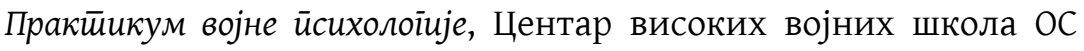
„Маршал Тито“, Војна академија КоВ, Београд. Може се рећи да је то ठило време удруживања психолога из Војне академије, Војномедицинске академије, и психолога са Универзитета у Београду.

Мајор и магистар психолошких наука Петар Костић у периоду од 1984. године па надаље аутор је више чланака. Сарађује у истраживању са психолозима и андрагозима из Војне академије, Војномедицинске академије, Војне гимназије и Института ратне вештине. Истражује континуиране психолошке теме важне за динамику војне организације као што су функционисање питомачких колектива, прилагођеност условима школовања и полигонским условима (Пајевић, Маравић, Костић, 1987); особине личности питомаца као корелати успешности у улози командиpa (Костић, 1987); пожељне психолошке особине личности официра наше и страних армија (Костић, 1984); васпитање у војном колективу коришћењем личног примера (Килибарда и Костић, 1990). Интензивно ради на испитивању метријских карактеристика психолошких тестова које је и сам примењивао током психолошке селекције за пријем у војне академије (Костић и Миловановић, 1987), али и за потреље селекције ученика за средње војне школе (Костић и Миловановић, 1987) и војну гимназију (Костић и Љубичић, 1984), као и на задацима у тиму доктора психолошких наука Пере Шипке о валидацији скале Л из Ајзенковог теста личности (Шипка, Ловре, Косановић, Костић, 1988). 
У разматраном периоду објављене су четири докторске дисертације војних психолога који су дали значајан допринос развијању предмета војне психологије и реализацији наставе у Војној академији:

Докторске дисертације:

1) Пајевић, Д. (1981). Психолошки и соицјално-економски факйори као gеиеерминаниеие избора занимања. Филозофски факултет, Београд.

2) Шипка, П. (1984). Послеgице излаїања неконирролибилним исхоgи-

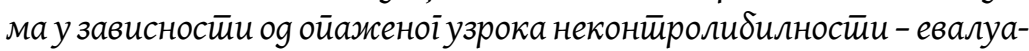
иција йеорије научене ঠесйомоћносий, Филозофски факултет, Загреб.

3) Касагић, Љ. (1984). Оріанизација и интетеракциија особина личносиии као чинилац васӣийно-образовне усйешносиии, Филозофски факултет, Скопје.

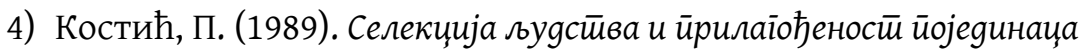
захиеевима војне оріанизаиције, Филозофски факултет, Сарајево.

РАДОВИ ИЗ ВОЈНЕ ПСИХОЛОГИЈЕ У ПЕРИОДУ ОД 1991. ДО 2000. ГОДИНЕ И НАКОН ПРЕСТАНКА ПРОФЕСИОНАЛНЕ ВОЈНЕ СЛУЖБЕ

Потпуковник и доктор психолошких наука Петар Костић у периоду од 1991. до 2000. године наставља сарадњу са професорима Пајевићем и Касагићем. У Војној академији постаје наставник војне психологије на Катедри друштвених наука, а 1993. године асистент професору др Љубомиру Касагићу. Тај период карактерише неколико истраживачких задатака - Уџбеник из криминалистичке психологије за Вишу школу унутрашњих послова (Костић, 1998), објављена је једна засебна студија о проблемима

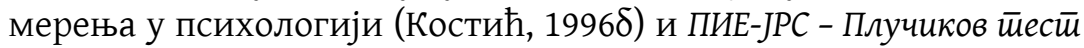
емоиија, Приручник - јуіословенска ревизија и моgификација (Костић, 1997). Током 1996. године пуковник Костић Петар постаје начелник Одсека психолошке службе Одељења за психолошко-пропагандно деловање, Управе за информисање и психолошко-пропагандна дејства Генералштаба Војске Југославије.

„Када је реч о чланцима који су објављени у овом периоду, проф. др Десимир Пајевић, проф. др љубомир Касагић и проф. др Петар Костић, са сарадницима, објавили су укупно 19 чланака у домаћим часописима и зборницима. Истовремено ови аутори, са сарадни- 
цима, учествовали су на Симпозијуму из ваздухопловне медицине и психологије, на научним скуповима 'Емпиријска истраживања у психологији', као и на Сабору психолога са 13 научних саопштења“ (Марчек, Пешић, 2020).

Професор Костић наставља са психометријским тестирањем инструмената ММПИ-201 (Костић и Ловре, 1991), тестовима способности за учење као ситуационим тестовима у школској селекцији кандидата (Костић, 1992, стр. 128-144); PNEL Реконструкциja, ревизија и стандардизација најновије верзије Ајзенковог упитника EPQ (Момировић, Хошек, Костић, 1996, стр. 159-168); новим начинима утврђивања симптоматске ваљаности тестова (Костић, Анђелковић, 1998, стр. 385-396); испитивањем да ли је погрешна Ајзенкова теорија личности или је погрешан тест EPQ (Момировић и Костић, 1998, стр. 86-119). Истражује: моделе селекције људи (Костић, Миловановић, Гојић, 1997, стр. 154-169); разматра психологију ратног злочинства (Костић, 1996а, стр. 447-464); посттрауматски стресни поремећај ратних рањеника (Трлаја, Костић, Дедић, 1997, стр. 425-436).

Својим истраживањима хтео је:

- доказати да тест способности за учење може функционисати као ситуациони тест у школској селекцији кандидата, омогућавајући предвиђање њиховог прилагођавања и ефикасности у друштвеној институцији школе. Конструисањем мање ситуације учења, ангажовањем когнитивних и конативних карактеристика испитаника, могу се проценити особине личности кандидата: навике и технике у процесу учења, емоционална стабилност кандидата, тип нервног система и анксиозност у испитним ситуацијама. У више испитивања на преко 3.000 испитаника емпиријски је доказао дијагностичко мотивациону, когнитивну и конативну, као и прогностички когнитивну и конативну ваљаност теста способности за учење, али у поређењу са најчешће коришћеним тестовима способности (Костић, 1992, стр. 128-144);

- да укаже на важност сталног праћења и анализе ефикасности психолошких критеријума, инструмената и поступака везаних за селекцију (Костић, Миловановић, Гојић, 1997, стр. 154-169);

- да покуша на основу опсервација током боравка на ратишту да дубље истражи околности и чиниоце који одређују ратно злочинство у оружаној борби; указао је на чиниоце који под- 
стичу нехуманост у рату и да они обухватају ситуационо-тактичке, нормативно-борбене, друштвене и конкретним борбеним околностима одређене услове; основни налаз је да околности више доприносе чињењу ратног злочина него личност његових починилаца (Костић, 1996а, стр. 447-464);

- провери психолошку чињеницу да људи различито подносе животни стрес у зависности од индивидуалне структурне еластичности која је повезана са социјално-психолошким чиниоцима животног окружења; разматрао је неке психолошке разлике међу ратницима спрам војника ठез ратног искуства и ратних рањеника са и ठез посттрауматског стресног поремећаја, основни налаз је да ПТСП-рањеници постижу значајно ниже скорове на димензијама инкорпорације, заштите и репродукције и више скорове на димензији агресивности (Трлаја, Костић, Дедић, 1997, стр. 425-436).

„Период од 1991. до 2000. године, осим радова везаних за војнообразовне и проблеме обуке питомаца, носио је бројне изазове за војну психологију, што најбоље показују књиге проф. др љубомира Касагића и проф. др Петра Костића („Психологија за војног старешину“, 1992), а нарочито књига проф. др Петра Костића („Психологија борбених јединица“, 2000) и неколико чланака који се односе на психолошка истраживања везана за рат (Костић, П., Физичка способност појединца и његово понашање у миру и рату, 1995; Костић, П. Прилог психологији ратног злочинства, 1996; Трлаја Љ., Костић П., Дедић Г., Посттрауматски стресни поремећај ратних рањеника, 1997)“ (Марчек и Пешић, 2020).

Књига двојице професора војне психологије у Војној академији Љубомира Касагића и Петра Костића (1992) Психолоіија за војної стиарешину обима 192 стране, састоји се од 12 тематских целина. Тематске целине су писане са циљем едукације студената-кадета будућих официра и официра у војној организацији, дајући им шира знања из теоријско-методолошких области психолошке науке; обрађене су теме психолошких аспеката борбене обуке и васпитања преко објашњења психолошких принципа, врста учења и трансфера учења током стројеве обуке, обуке из наоружања, тактичке обуке, физичке обуке, моралног и војничког васпитања; теме о особинама личности, познатим теоријама личности, факторима формирања личности као и представљање резултата истраживања особина личности као фактора васпитнообразовне успешности и развоја личности. Незаобилазне теме су и настанак и развој структуре војне јединице са нагласком на важност 
војног руковођења и командовања, као и формалног и суштинског ауторитета старешине и неопходност стварања кохезивности војног колектива изградњом добрих међуљудских односа правичним командовањем. објашњени су психолошки проблеми прилагођавања војника на војничке услове живота, критеријуми који указују на степен прилагођености или неприлагођености војној средини, као и дефинисање која се све понашања сврставају у неприлагођеност, као и како поступати са таквим војницима. Свесни да војни колектив чине људи и да војни колектив као специфична војна целина постоји у мирнодопском времену, а од посебног је значаја у ратном периоду, објаснили су могуће психичке поремећаје и обољења људи и значај и методе рада ментално-хигијенских тимова.

Све време свог наставног ангажовања у Војној академији професор Костић сарађује са истраживачима Института ратних вештина каснијим Институтом за стратегијска истраживања, где једно је време и формално био запослен у Одељењу за стратегију, Одсеку за војну психологију, андрагогију и социологију. Сарађује са андрагозима: пуковником проф. др Јаном Марчеком, пуковником проф. др Зораном Килибардом и пуковником проф. др Будиславом Сушом.

Мишљења истраживача војне психологије, студената Војне академије, војних психолога са искуством из грађанских ратова и одбране земље током НАТО агресије 1999. године, као и официра некадашњих студената професора Костића су да је пуковник и професор Петар Костић сва своја војничка и психолошка знања и ратна искуства сажео у публикацију Психолоїиј борбених јеguниц̧а из 2000. године.

Професор Костић, не случајно, публикацију започиње поглављем о моделима и стратегијама развоја психолошке службе у војсци, указујући на важност снажне војно-психолошке службе за селекцију и рад са војничким колективом. Наставља објашњавањем: психо-социјалних карактеристика регрутне популације која на служењу војног рока утиче на формирање војног колектива; сталног задатка потребе очувања менталног здравља војника, важности ментално-хигијенског рада трупног психолога, облике (не)зрелог, (не)прилагођеног понашања у војној средини. Тежиште објашњења са регрутне популације преноси на војну популацију, веома рационално и искуствено, указујући на важност професионалне психолошке селекције војног људства, као једног од најважнијих фактора формирања војног колектива, са 
високим вредностима мере кохезивности, добрих међуљудских односа и принципијелног командовања старешина, суштинских ауторитета створених на основу личног примера са ретким ослањањем на формални ауторитет. Свестан да мир у земљи није једини фактор мира у војној организацији, објаснио је психолошке аспекте ванредних догађаја у војсци са акцентом на самоубиство. Као учесник грађанских ратова, зналачки је објаснио и указао на значајне сегменте војничког образовања, војничке обуке и добре физичке кондиције и менталног здравља као факторе превенције јављања менталних поремећаја у рату, али и као факторе $\delta$ pжег опоравка од физичког рањавања и менталних траума. објаснио је порекло мотивације борца, као појединца и члана војне групе, важност појединачне и колективне припреме за рат и

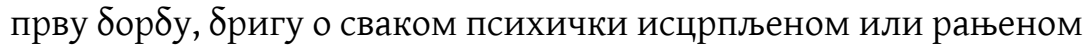
члану војног колектива, борбени стрес и посттрауматски стресни поремећај искуствима и из страних армија. Посебно је указао на улогу бригадног психолога у рату, приказавши подсетник за рад трупног психолога бригаде у рату, принципе рада, задатке и методе рада с обзиром на време рата, задатке и методе рата и с обзиром на учеснике у рату.

Истраживачке теме којима ће професор Костић посветити своје време и по одласку у пензију су психологија ратног злочинства (са освртом на основна правила хуманитарног права, чиниоце који, по логици борбе, подстичу нехуманост у рату, особине личности ратних злочинаца, стално питање шта одређује ратни злочин: личност или околности?, типичне ситуације у којима се чине ратни злочини као и ере и поступке за смањење бруталности у рату); психолошка искушења ратног заробљеништва (са препорукама о психолошкој припреми бораца за случај пада у заробљеништво, фазе ратног заробљеништва, психолошки поступци саслушавања ратних заробљеника („Испирање мозга“), као и последице заробљеничког живота.

Свестан да живот после рата није исти без обзира на степен образовања, успешност у послу, складних пријатељских и топлих породичних односа, објаснио је које су нормалне промене понашања ратника после рата: да ли су „нормалне“ промене понашања ратника нормалне, које промене понашања ратника нису психијатријски поремећаји, које су врсте и механизми промене понашања и колико је трајање тих промена.

Књигу у којој је зачео свој војнички живот и ратна искуства, пуковник и професор Петар Костић посветио је првенствено сво- 
јим ратним друговима, наводећи их личним именом, једном капетану - команданту, једном генералу од којих је Петар учио војничке вештине, поручнику од којег је учио падобранске вештине, али и знаним и незнаним погинулим, рањеним, и живим ратницима Србима, Хрватима, Муслиманима и Албанцима, које је сретао војнички и људски у Славонији, Лици, Далмацији, Косову и Метохији током грађанског рата на тлу СРФ Југославије и током „агресије НАТО-а на моју домовину“ (Костић, 2000).

Књига је настала уз помоћ колега психолога Војске Југославиje, а највећи допринос су дали: Јован Милојковић, Драгана Аларгић, Љиљана Трлаја, Нада Данић, Јованка Јелић, Татјана Стефановић-Станојевић, Дејан Јанковић, Властимир Цветковић и Драган Зенковић (Костић, 2000).

Познато је да је професор Костић учествовао на научно-стручном скупу „Емпиријска истраживања у психологији“ у организацији Филозофског факултета у Београду презентујући своја истраживања и својих сарадника психолога из јединица војске. Нека од истраживања су:

- о личносним корелатима позитивног става према самоубиству, истраживања које је имало за циљ проналажење ефикасног начина откривања војника који припадају „ризичној групи“ за покушај или извршење самоубиства као начина решавања животних проблема (Костић, Пантелић, Бијелић, Стефановић-Станојевић, Јеленковић, 1996);

- утврђивање разлика у емоционалном реаговању између људи који су ठили под стресом и успешно га превладали и оних који су у стресној ситуацији доживели физичку трауму, на узорку од 419 испитаника, ратника младића из грађанског рата са славонског ратишта (1991-1992) и испитаника трауматске групе зрелих мушкараца са борбеним искуством који су у истом рату доживели тешка рањавања; испитани су Плучиковим тестом (југословенском ревизијом и стандардизацијом); ратници показују снижену „заштиту“, „репродукцију“ и „БИАС“, а повишену „оријентацију“ и „лишеност“; рањеници имају још више изражену „лишеност“, али за разлику од ратника снижена им је „оријентација“, док им је „заштита“ повишена (Костић и Данић, 1998, стр. 37).

У периоду после 2000. године професор Костић наставља сарадњу са професорима: Момировићем, Пајевићем, Марчеком и психологом Војне академије Надом Данић. Теме његових истра- 
живања су: психопатија и депресивност (Момировић и Костић, 2003, стр. 573-586); особине личности и лагање (Костић и Лојић, 2004, стр. 277-283); питање о психометријској структури људске среће (Костић, Флере, Лаврич, 2007, стр. 163-178).

Због интересантности истраживања људске среће, која је важна општој популацији, а чини се пресудна у војничкој каријери, а и данас је честа мултидисциплинарна тема истраживања, преносим у целости резиме чланка. Из којих мотива и углова, и на који начин је професор Костић гледао на срећу и како ју је осећао може се закључити из цитата:

„Може ли се, а ако може, како се може, дефинисати и операционализовати људска срећа? Овај проблем смо истражили на великим узорцима испитаника (Н>9000). Срећа постоји зато што прожима све што појединац осећа, мисли и ради, а што је уграђено у скоро све домене и аспекте личности. Срећа није у новцу, али су због његовог недостатка људи несрећни. Срећан млад човек, пре него што уђе у колотечину зрелости, може умрети да $\delta$ остварио своје идеале. Најзад старије срећне особе су здраве, ушушкане у породицу, имају активан стил живота и рекреацију. Све ове одговоре, добили смо разноврсним статистичким техникама (линеарним корелацијама, факторском анализом, хи-квадрат и т-тестовима) применом три основна мерна инструмента: скалом среће, структуралним тестовима личности (НЕО-ПИР и ПФМ) и тестом емоционалних димензија (ПИЕ/JРС)“ (Костић, Флере, Лаврич, 2007, стр. 163-178).

Истраживања наставља испитивањем психометријских карактеристика инструмената и презентовањем резултата на научним скуповима „Емпиријска истраживања у психологији“ на Филозофском факултету Универзитета у Београду.

Издвајају се нека од њих:

- провера интерне поузданости и временске стабилности психолошких и педагошких тестова, техника и скала, и то: тестова успешности: тестова развојних нивоа, тестова интелигенције, општих когнитивних тестова (пажње, концентрације и сл.), тестова школске успешности и тестова знања, тестова посебних когнитивних функција (спретности, моторика итд.); 2) психометријских тестова личности: структуралних тестова личности (инвентари), тестова ставова и интересовања, клиничких тестова личности (психодијагностички); 3) пројективних тестова личности: тумачења форми (Roršah, TAT, итд.), Вербално-тематских техника (нпр. 
TNR), Технике засноване на цртању и обликовању (нпр. Mahover тест) (Костић, 2001, стр. 33).

- испитивање три извора детерминације по Буквићу, за тестове (EPQ, PIE-JRS, PNEL, BOL-TNPS I NEO-PI R) који су задавани испитаницима (H=1942) у различитим ситуацијама и дали су различите индексе поузданости (Костић, 2002, стр. 29).

На лични захтев, 2004. године, пуковник и професор Петар Костић одлази у пензију са места руководиоца Групе наставе војне психологије на Катедри војне психологије андрагогије и морала Војне академије.

Од 1998. године, паралелно са радом у Војној академији, професор Костић ангажован је на Филозофском факултету у Нишу на Департману за психологију, где студентима предаје предмете Психометрија и Војна психологија. Први асистент на предметима постаје психолог Миодраг Миленовић, бивши војни психолог. Својим предавањима и представљањем војне организације и улоге војних психолога, заинтересовао је студенте за рад у војсци по дипломирању. Из прве класе студената психологије у Нишу су психолози: Радмила Ступа-Ђуришић касније војни психолог у Подгорици, и ја-психолог у Регрутном центу ВЈ, потом истраживач у Института за стратегијска истраживања Одсеку за војну психологију, андрагогију и социологију, место истраживача у Институту на којем је радио и пуковник и професор Петар Костић. Наша сарадња, која почиње на факултету 1998. године на основним студијама, наставља се током 2004. и надаље током последипломским студија, након 2006. године рецензирањем радова Института, консултацијама, 2011. године предлогом и почетком рада на писању уџбеника из војне психологије за потребе студената Војне академије, на основама претходних уџбеника на којима је професор био аутор или коаутор. Нажалост, до краја задатака израде уџбеника из војне психологије, није дошло. У том периоду у складу са све већим значајем информационог окружења и коришћења интернета и нових технологија, професор и ја заједно реализујемо емпиријско истраживање на узорку студената Војне академије и цивилног факултета.

Наше заједничко истраживање проблема информационог деловања, коришћења интернет мреже и сајбер простора, осавременило је приступ истраживању о факторима прилагођавања кадета условима школовања у Војној академији и факторима образовне ефикасности. Употреба интернета током школовања новијих 
генерација свакодневна је потреба. Садржаји који се могу наћи на различитим сајтовима неопходни су због опште информисаности, али су и у функцији свакодневног учења. Мноштво података који се могу пронаћи на интернет мрежи, неретко одузму пратиоцу сајтова и више времена од планираног. Уочено понашање може се окарактерисати и зависничким понашањем. „Додатним истраживањем 206 студената, од којих 83 кадета са Војне академије и паралелни узорка 123 студената Филозофског факултета анализирани су психолошки чиниоци који корелирају са компулсивним коришћењем интернета на уштрб свих других манифестних облика понашања. Први налаз истраживања је, да не постоји интернет зависност независна од других облика зависничког понашања (никотин, алкохол и психоактивне супстанце). У складу са овим налазом је логички повезано, да исти структурни делови личности детерминишу интернет зависничко понашање као и остале облике зависности. Највећи утицај на зависничко понашање испољава димензија личности авантуризма (15\%), ниска самоконтрола (6\%), ниска сарадљивост (6\%), ниска заштита (5\%), ниско истраживање (5\%), висока оријентација (4\%), висока агресија (4\%) и висока екстровертираност (4\%). Укупна детерминисаност интернет зависности особинама личности је $18 \%$. Закључујемо, да авантуризам и с њим повезане личносне структуре (ниска самоконтрола, сарадљивост, заштита и истраживање, а висока екстроверзија, агресивност и оријентација) одређују евентуалну интернет зависност. Наведене особине личности су потенцијална основа, а зависност од интернета манифестно исходиште“" (Борђевић, Костић, Милојевић, 2011, стр. 1641).

Стваралачки опус пуковника и професора Петра Костића у области војне психологије немогуће је приказати и исказати једним чланком. Многобројна емпиријска истраживања, научни радови, учешћа на научним и стручним скуповима психолога, студије, анализе, публикације, рецензије пројеката, психолошки критеријуми за пријем у војну професију и каријерно вођење указују на професорову разноврсност интересовања и свеобухватну укљученост у све сегменте војне професије и улоге човека у одбрани током мирнодопског и ратног периода. Већина радова професора Петра Костића може се погледати на сајту www.psihometric.com.

Током посета Институту за стратегијска истраживања, у разговорима са колегама о приватном животу причао је о његовом родном Златибору, родитељима, супрузи и времену које проводе 
у лепотама и ћудима планине. Указивао је поготову млађим колегама Института колико је важан породични живот за једног старешину, а поготову за старешине и људе, који су имали „среће“ да упознају рат и борбу, што није желео више ниједној генерацији старешина. Говорио је колику му надљудску снагу дају његови унучићи Алекса, Теодора и Нина, и да за ту снагу није знао док их није добио, а које су му „подариле“ његове ћерке, „његове мезимице“ Александра, с поносом оца, војни психолог и Ксенија, молекуларни биолог, која живи у Америци.

У Институту за стратегијска истраживања на дану јединице 2019. године, на коме су се окупили пензионисани и садашњи припадници и сарадници Института, одата је пошта уваженом колеги и ратном другу.

Ових дана, док настаје овај текст у време прве годишњице од смрти пуковника и професора Петра Костића у паузи и разговорима причају се анегдоте: са испита у Војној академији - где је професор направивши тест у свом стилу са доста питања и са још више понућених одговора рекао кадетима да слободно могу да ставе на сто своје књиге и ठелешке, што је кадете зачудило, али кад су видели тест схватили су да им књига не може помоћи; са предавања: кад је професор у жељи да укаже на важност поштовања распореда часова и војничке дисциплине рекао да ако он закасни на предавање да га слободно могу тражити у Полиӣuщ̧и на последњим странама и како се десило да га је задржао начелник Војне академије шаљиви кадети на наставничкој катедри су оставили примерак Полийике отворен на последњој страни и написали поруку „Нема Вас, ми смо отишли“; анегдота из тролејбуса 41: професор и ја смо пошли до Војномедицинске академије тролејбусом који пролази поред Војне академије, професор се прекрстио, увидевши мој упитни поглед одговорио ми је: „Побогу, колегинице, па људи се крсте у превозу кад пролазе поред Храма Светог Саве, а да га нису ни посетили, ја сам цео свој живот провео у Војној академији, могу и ја да се прекрстим“.

Усменом анкетом припадника Института, дошла сам до емпиријских података. Најфреквентнији одговори на питање „Како ठисте са неколико речи описали професора Костића?“ ठили су: изузетан и занимљив предавач, добар познавалац војске који је приближио теорију и праксу војне психологије, неконвенционалан у најбољем смислу те речи, ауторитет у психолошкој пракси, врло интелигентан, ексцентричан, живахан, динамичан, жељан знања, иноватор, доследан друг, поверљив класић и лојалан сабо- 
рац. И како ठи професор то рекао себи: „Петре, добро си то урадио!“.

Нама остаје да сваког дана градимо своје ликове и дела најбоље што можемо и по узору на пуковника и професора Петра Костића и других наших професора, а у складу са очекивањима која су имали од нас, јер човек живи док живе његова дела и људи причају о њему.

ЛИТЕРАТУРА Ђорђевић, А., Костић П., Милојевић А. (2011). Психолошки профил интернет зависника. Теме, 4, 1641-1656.

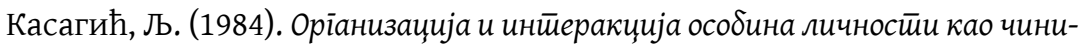
лаи васиииеино-образовне усйешносиии (докторска дисертација). Скопље: Филозофски факултет.

Касагић, Љ., Костић, П., Бауцал, Д., Зорић, Д. (1979). Неки йроблеми форми-

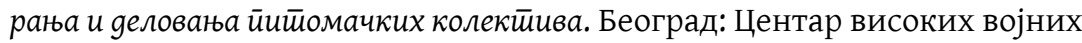
школа - Војна академија родова КоВ и интендантске служठе.

Касагић, Љ., Пајевић, Д., Костић, П., и Ловре М. (1990). Пракӣикум војне йсихолоїuје. Београд: Центар високих војних школа ОС „Маршал Тито“ Војна академија КоВ.

Касагић, Љ. и Костић, П. (1992). Психолоїија за војної сииарешину. Београд: Центар високих војних школа ОС „Маршал Тито“ - Војна академија КоВ.

Килиठарда, З. и Костић, П. (1990). Васпитно деловање командира питомачког вода личним примером. Теорија и ӥракса райне вешйине, 20.

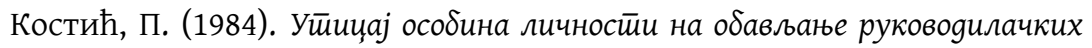
улоіа у војном колекиеиву. Београд: Војна академија КоВ.

Костић, П. и Љубичић, В. (1984). Узастопно испитивање ваљаности стандардизованог психолошког интервјуа. Ревија за йсихолойuју, 1-2.

Костић, П. (1984). Пожељне особине личности официра неких савремених армија. 38орник раgова ВА КоВ, 10.

Костић, П. (1987). Особине личности питомаца као корелативи њихове успешности у командирским улогама. 3борник раgова ВА КоВ, 13.

Костић, П. и Миловановић, Р. В. (1987). Валидација селекционих ठатерија за средње војне школе и војне академије. Теорија и райна йракса, 3, 147185.

Костић, П. и Ловре, М. (1991). Норме и дијаграм профила на тесту ММПИ-201 за полно, образовно и узрасно хомоген узорак. Психолоіија, 24, (1-2), 180-186.

Костић, П. (1992). Тест способности за учење као ситуациони тест у школској селекцији кандидата, Психолоіија, 25, (1-2), 128-144.

Костић, П. (1995). Физичка способност појединца и његово понашање у миру и рату. 3борник Полицијске акаgемије. 
Костић, П., Пантелић, Љ., Бијелић, Д., Стефановић-Станојевић, Т., Јеленковић, Д. (1996). Личносни корелати позитивног става према самоубиству. Друіи научни скуй Емйиријска исиираживања у йсихолоїији. Београд: Филозофски факултет.

Костић, П. (1996а). Прилог психологији ратног злочинства. Психолоїија, 29 (4), 447-464.

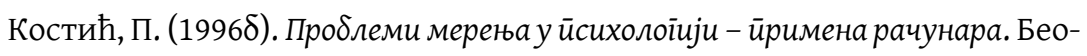
град: Институт за криминолошка и социолошка истраживања.

Костић, П. (1997). ПИЕ-ЈРС - Плучиков иеести емоциија, Приручник - јуїословенска ревизија и моgификација. Београд: Друштво психолога Србије - Центар за примењену психологију.

Костић, П., Миловановић, Р., Гојић, А. (1997). Модели психолошке селек-

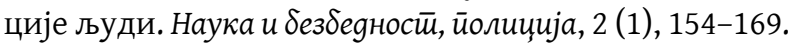

Костић, П. (1998). Криминалисі̄ичка ӣсихолоїија. Београд: Виша школа унутрашњих послова.

Костић, П. и Данић, Н. (1998). Слике Стреса и трауме на тесту ПИЕ-JРС.

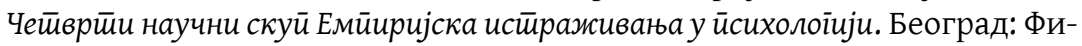
лозофски факултет.

Костић, П. и Анђелковић, 3. (1998). Нов начин утврђивања симптоматске ваљаности тестова. Психолоїја, 31 (4), 385-396.

Костић, П. (2000). Психолоїија борбених јеgиница. Београд: НИЦ „Војска“.

Костић, П. (2001). Интерна поузданост и временска стабилност психолошких и педагошких тестова, техника и скала. Сеgми научни скуй Емйиријска исйраживањ у йсихолоїији. Зборник резимеа, стр. 33. Београд: Филозофски факултет.

Костић, П. (2002). Детерминанте поузданости тестова. Осми научни скуй Емйиријска исйраживањ а у ӣсихолоїији. Зборник резимеа, стр. 29. Београд: Филозофски факултет.

Костић, П. и Лојић, Р. (2004). Лагање и личност. Теме, 28 (3), 277-283.

Костић, П., Флере, С., Лаврич, М. (2007). Психометријска структура људ-

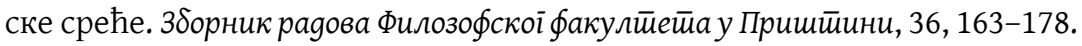
Марчек, Ј. и Пешић, А. (2020). Развој научноисӣраживачке мисли војне йсихолоїије. Београд: МЦ „Одбрана“ (у процесу штампе).

Момировић, К., Хошек, А., Костић, П. (1996). PNEL Реконструкција, ревизија и стандардизација најновије верзије Eysenckovog упитника EPQ. У: П. Костић (ур.), Мерење у йсихолоїuјu 2 (159-168). Београд: Институт за социолошка и криминолошка истраживања.

Момировић, К. и Костић, П. (1998). Погрешна теорија или погрешни тестови: Резултати добијени анализом најновије верзије Eysenckovog

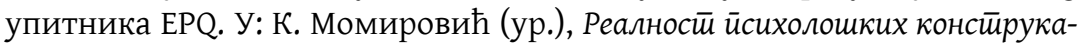
$\bar{u} a$, Симйозијум 1 (86-119). Београд: Институт за социолошка и криминолошка истраживања. 
Момировић, К. и Костић, П. (2003). Психопатија и депресивност. Теме, 27 (4), 573-586.

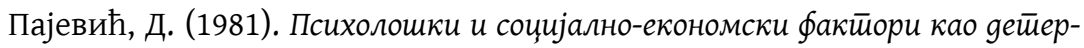
минанӣе избора занимања (докторска дисертација). Београд: Филозофски факултет.

Пајевић, Д., Ловре, М., Маравић, Г., Костић, П. (1987). Вреgносне оријенӣ $а-$

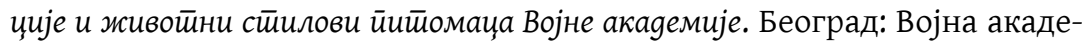
мија КоВ.

Пајевић, Д., Маравић, Г., Костић, П. (1987). Утицај особина личности на прилагођеност питомаца полигонским условима. Зठорник pagoва ВА КоВ, 13, 85-97.

Марчек, Ј. и Пешић, А. (2020). Развој војне психологије у Србији у војним научним и наставним институцијама. У: А. Пешић (ур.), 70 іоgина војне йсихолоїuје у Србији 1947-2017. Београд: МЦ „Одбрана“ (у процесу штампе). Пајевић, Д., Требјешанин, Б. (1988). основи ӣсихолоїије ойшйенароgне оg-

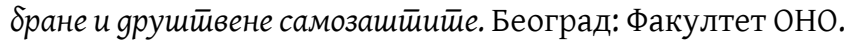

Трлаја Љ., Костић, П., Дедић, Г. (1997). Посттрауматски стресни поремећај ратних рањеника. Психолоіија, 30 (4), 425-436.

Шипка, П. (1984). Послеgице излаїања неконитролибилним исхоgима у зави-

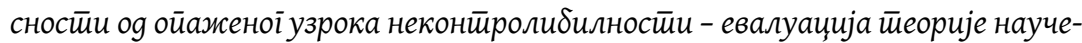

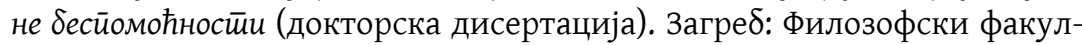
тет.

Шипка, П., Ловре, М., Косановић, Б., Костић, П. (1988). Екстерна валидација скале L из Eysenckovog теста личности EPQ. Ревија за йсихолоїuјy, 12,9-17.

Momirović, K., Džamonja, Z., Hošek, A. i Wolf, B. \& Gredelj, M. (1981). Struktura antropoloških dimenzija vojnika JNA. Beograd: Vojnomedicinska Akademija/ VMA.

ANITA S. PEŠIĆ

University of Defence, StRATegic Research InStitute

SUMMARY

\section{ABOUT THE CHARACTER AND WORK \\ IN THE FIELD OF MILITARY PSYCHOLOGY \\ COLONEL AND PROF. DR. PETAR KostiC}

This article presents a good part of the oeuvre of the research work of Colonel and Professor Dr. Petar Kostic in the field of military psychology. The scientific research work of the professor is presented at intervals, following the project cycles of research, but also with the specific professional development of the officers. Published 
papers, studies, articles, presentations at scientific and professional meetings that show the tendencies of teamwork of psychologists in military education and health, as well as a multidisciplinary approach to problem research, where military psychologists, sociologists and psychiatrists were often members of the team of military psychologists. The article covers 4 sections presenting Professor Kostić's research work since his arrival at the Military Academy, his work at the Institute of War Arts at the latter Institute for Strategic Research, Directorate for Information and Morale of the General Staff of the Army of Yugoslavia, as follows: 1) from 1974 to 1980; 2) from 1981 to 1990 ; 3) from 1991 to 2004 and upon termination of professional military service, with presentation of characteristic features, ways of thinking and work, and procedures towards cadets, students and senior staff. By analyzing the scientific works, it can be concluded that Professor Kostic is one of the founders of military psychology in these areas (Socialist Federal Republic of Yugoslavia Republic of Serbia), together with the initiators of the idea of the application of psychological knowledge in the military environment, started and led by Professors Desimir Pajević and Ljubomir Kasagić. It is impossible to present in one article the scientific work of Colonel and Professor Petar Kostic. This article presents papers that introduced novelty into the professional psychological selection of military personnel through their topicality and innovation. Works describing the character and work of Colonel Kostic and presenting a synthesis of psychological and military life and work are presented.

KEYWORDS: defense man; officer; scientific research; military psychology.

Овај чланак је објављен и дистрибуира се под лиценцом Creative Commons Ауторство-Некомерцијално Међународна 4.0 (CC BY-NC 4.0 |

https://creativecommons.org/licenses/by-nc/4.0/).

This paper is published and distributed under the terms and conditions of the Creative Commons Attribution-NonCommercial International 4.0 licence (CC BY-NC 4.0 | https://creativecommons.org/licenses/by-nc/4.0/). 